\title{
The Great Departure: Rethinking National(ist) Common Sense
}

Author. Dace Dzenovska is a Senior Researcher / Marie Curie Fellow at the Centre for Migration, Policy and Society, University of Oxford. Correspondence to: Dace Dzenovska, COMPAS, University of Oxford, 58 Banbury Road, Oxford, OX2 6QS, email: dace.dzenovska@gmail.com

Abstract. This article argues that in order to overcome the national(ist) common sense that continues to haunt everyday, political, and scholarly interpretations of mobility, scholars need not diagnose nationalism with greater vigour, but rather move beyond facile diagnoses of nationalism. The article calls for a meticulous tracing of relations and practices of emplacement and displacement that ubiquitous national(ist) interpretive frames both coopt and exceed at the same time. The argument is elaborated on the basis of an analysis of historical articulations of emplacement and displacement in Latvian understandings of the good life. The article pays particular attention to the ways in which the figure of the migrant has emerged historically as an aberration to Latvian understandings of the good life. It also considers how this ethical configuration is being unsettled through massive labour migration to Western Europe-or 'the Great Departure'.

Keywords: mobility, emplacement and displacement, national(ist) common sense, Latvia.

\section{The Great Departure as a Site of Possibility}

In December of 2009 I was standing in line at the gate of the Ryan Air flight from London to Riga. I was moving to Riga after many years of back and forth between New York, San Francisco, and Riga to take up a three-year research job affiliated with the University of Latvia. Financed by the European Social Fund, my employment was conceived as 'bringing back the human resources' that had left the Latvian nation-state to study or work elsewhere. I was thus a prime subject of a policy articulated in the spirit of 'the national order of things', that is, a policy that posited a necessary link between particular bodies and particular territories and that furthermore took the system of nation-states as a natural formation within which life, including mobility, is organized (Malkki 1992, 1995, Gupta and Ferguson 1992, Torpey 1998, Balibar 2010, Wimmer and Glick-Schiller 2002). Within this national order of things, people who had left their 'country of origin' , 
or, more precisely, people who had left their 'country of origin' and were thought to possess skills and knowledge rather than constitute a burden on the social budget, were best returned to it.

On that winter day, I was not the only one in the Ryan Air line who could have been marked as returning in one or another sense of the term. Most people in the line and later on the plane identified each other as fellow travellers through their shared experiences of working and living away from home or of crafting home between two or more places (Lulle 2010). People asked one another where they were coming from, that is, from which part of Great Britain, Ireland or elsewhere in Europe they had travelled to board this Ryan Air flight from London to Riga. After assessing the length of travel to the airport, the conversation turned to the town or the village to which each was going. Two women sat on either side of me, one with a 15-month old baby. Talking, we quickly established that both women came from Daugavpils - a city in the southeast Latvia-and now lived in London. The woman with the baby arrived in London seven years ago, got married, and now was hoping to have another child. She was going to visit her 70-year old mother who refused to move, as well as to purchase a washing machine. The other woman-in her 60shad lived in London for four years with her whole family and was travelling to Daugavpils to overlook the renovation of the apartment she owned there, as well as to visit with her friends. She said they worked hard and lived well in London and that her son did not want to go back for a visit, because he did not want to be upset by his friends' poverty. In recognizing each other as fellow travellers, we did not form bonds on the basis of national belonging. In fact, our national belonging would have been differentiated in Latvia, since I spoke Latvian, while the other two women spoke Russian. Rather, we found solidarity in our shared experiences of movement, labour, and the long absence from home.

My travel companions' and my traversals were profoundly shaped by the national order of things. My moving to Riga was made possible by patterns of resource distribution that attempted to re-establish links between particular bodies and particular territories even as I hardly saw myself as a returning national. In turn, my travel companions' mobile practices were made possible by particular relationships between states and their citizens formed within the uneven configuration of power relations that is the European Union. Most of the older European Union member states instituted temporary restrictions on the movement of the labour force from the new Eastern European member states when these joined in 2004, thus rendering freedom of movement a good accessible only to 
those deemed mature enough to make good use of it. England and Ireland became favourite destinations for Latvia's residents seeking work abroad because these states, along with Sweden, did not institute such restrictions.

In Latvian public discourse, the massive labour flow to London, Dublin, and other Irish and British cities, towns and villages tends to be talked about as 'the Great Departure'.[1] Most people's lives, whether of those who stay or of those who move, are shaped by the Great Departure. Knowledge about the phenomenon of the Great Departure is largely produced through people's situated reflections about their surroundings. For example, when suggesting that the scale of departure is noteworthy, people count how many of their peers (usually taken to be one's cohort at the university or high school as far back as 20 years ago) are still around and how many are known to have left. People note that houses and apartments in the areas they live in stand empty, that schools lack children, and that there are considerably less people in the streets than there were 10 or 20 years ago. Media reports contribute to the shared sense that something consequential is under way. Social media sites circulate cynical jokes calling for the last person at the airport to turn off the light, as one would when leaving one's home.

Parallel to the commentary on the reconfiguration of the social fabric and the material environment, there is also public concern with the consequences of the Great Departure for the nation. Policy makers, politicians, and intellectuals have begun to articulate this concern through a discourse on 'the problem of emigration' (SAK 2006, Hazans 2005, 2011). When talking about the problem of emigration as a matter of policy and political concern, focus shifts from tangible social and material relations to ever-elusive statistical enumerations of the extent of emigration and to debates about the effects of emigration on the economy, the demographic situation, and other matters pertaining to the life of the nation. For example, economist Mihails Hazans (2011) has estimated that about 250,000 people have left over the last decade. The latest population census suggests that the population has dropped from 2.38 million in 2000 to 2.07 million in 2011.[2] Economists, geographers, and demographers prognosticate that the population might drop further to well below two million by 2030, which would mean a severe shortage of the working-age population to support the non-productive segments of society as well as a serious threat to the reproduction of the cultural nation.[3] Yet, while rendered 'real' through statistics, prognoses and scientific language, the problem of emigration is not simply out there. It is constituted through a number of historically formed discursive repertoires, including the pervasive power of the 
national order of things, modern scientific discourse, and modern practices of governing, which aim to cultivate a healthy and plentiful body whether conceived of as the nation or the population (Hacking 2007, Foucault 2003).[4]

In this article, I take the experiences of and commentaries about the Great Departure as a site for critical reflection on national(ist) common sense. In her seminal piece on the national order of things, Liisa Malkki (1992) speaks of national common sense to mark the ways in which the national order of things is not just something that exists in the realm of politics but also something that orients people's understandings of the world and their place in it. I borrow from her, yet I speak of national(ist) common sense to emphasize the ways in which the national order of things permeates ordinary worldviews, politics, practices of governance, as well as scholarship. Thus, I combine Malkki's concern with the national order of things with Ulrich Beck's (2004) concern with 'methodological nationalism' in the social sciences (see also Wimmer and Glick-Schiller 2002). As argued by the editors of this issue (Glick Schiller and Salazar this volume), the production of knowledge and academic perspectives about the movement of people continue to be affected by methodological nationalism, which they urge scholars to overcome.

However, how is national(ist) common sense to be overcome? As Glick Schiller and Salazar (this volume) point out by critically engaging Liisa Malkki's work, this cannot be done by simply replacing narratives of sedentarity with narratives of movement, for narratives of movement too risk endorsing the normality or historicity of stasis. Moreover, how is national(ist) common sense to be overcome in conditions when it is not just an artificial interpretive frame imposed upon social reality, but also a worldview that structures people's understandings of the world and the self, as well as forms individuals as particular agentful subjects? I argue here that it is the very same practices and discourses that are shaped by the national order of things and enframed by national(ist) common sense that should be excavated for alternative ways of seeing and conceptualizing mobility. To put it another way, I argue that revisiting discourses and practices that seem to be saturated by nationalism, methodological or otherwise, might produce analytical and political possibilities for loosening the grip of nationalism that shapes how ordinary people, policy makers, and academics alike understand and assess mobility.

This is an interpretive exercise of excavating or brushing away layers of national(ist) common sense that have pervaded popular discourse, as well as critical scholarship. For example, it means reconsidering how people, including scholars, 
make sense of the relationship between people and place or people and land. While there is a strand of anthropology that has renewed attention to concrete relationships to land and place as sites of agency and possibility rather than tradition and backward nationalism (e.g. Escobar 2001, Candea 2010, GibsonGraham 2006), many scholars have taken the well-founded anthropological critique of place and culture as bounded entities to the extreme by engaging in a fast-track identification of nationalism in any mention of people's relationship with place or land. This is especially so in Eastern European contexts which already enjoy the stereotype of being mired in backward cultural nationalism of the Herderian kind.

In undertaking this exercise, I draw on J.K. Gibson-Graham's critique of the tendency in left-oriented scholarship to write with the 'affect and attitude of entrenched opposition' (2006: xxv), namely the tendency to identify oppressive power structures offering little space for alternatives. Perhaps this is because alternatives are hard to see if one has been cultivated as a scholar in the tradition of leftist critique. In re-orienting scholarly affects and capabilities, Gibson-Graham urge a cultivation of the capacity 'to linger with the object and process of thought in a ruminative space of not knowing' and suggest that by doing so 'we might see that we possess the capability (and ever-present option) of opening to what is novel rather than familiar in situations' (2006: xxviii). They outline a number of techniques for cultivating oneself as 'a thinking subject within a politics of (economic) possibility':

Ontological reframing (to produce ground of possibility), rereading (to uncover or excavate the possible), and creativity (to generate actual possibilities where none formerly existed) (2006: $x x x$ ).

Inspired by their affective and analytical orientations, I turn to re-reading the discourses and practices of mobility that seem to be saturated by national(ist) common sense in search for that which might be 'novel in familiar situations'. In this small project of excavation, drawing on feminist geographer Doreen Massey $(2005,1994)$, I invite attention to practices and relations of emplacement. I think of emplacement as a partaking in tangible social and material relations and trajectories that make up particular places, subjects, and lives. I also think of emplacement as a site of analytical and political possibilities.

My argument draws on ethnographic data gathered during fieldwork in rural villages. It is elaborated on the basis of an analysis of the historical articulation of 
mobility and ethics in the Latvian social and political imaginary. Within this imaginary, the figure of the migrant emerges as an aberration to relations of emplacement that are constitutive of Latvian understandings of the good life. However, rather than diagnosing this ethical configuration as grounded in commonsense ideas about national rootedness (Malkki 1992), I suggest that it emerges from local understandings of emplacement which can be co-opted by national(ist) common sense, but are not in a necessary relationship to it.[5]

To summarize, then, I argue that practices of mobility are shaped by the material reality of the national order of things and that the national order of things also lends meaning to mobility in collective and individual narratives. At the same time, the experiences of mobility-and the associated emplacement and displacement-exceed their co-optation by national(ist) common sense. I suggest that identifying national(ist) common sense as an animating discourse about mobility oftentimes overlooks this excess. To unleash the analytical and political potential of this excess, one needs to undertake the work of excavation. This, in turn, requires bracketing facile diagnoses of nationalism.

\section{Emplacement and Displacement}

A documentary film produced by Laila Freimane and Ivars Zviedrs in 2007 draws a comparison between the departure to Ireland today and the deportation of many of Latvia's residents to Siberia in the 1940 s and 1950 s after the Soviet state marked them as enemies of the newly established regime. The opening cadre features an imagined border with Ireland marked by a sign that says Irija (Ireland), only the sign is altered by adding three letters in front to say Sibirija (Siberia).

The reference to Siberia suggests that the displacement entailed in the mass departure for Ireland is comparable in its violence to the displacement that resulted from the forced movement of people by the Soviet administration. At the end of the 1950s, when the Soviet administration was done with the deportations, many families had been destroyed or separated. Many homes remained empty and were later settled by incoming Soviet military officers or workers of the new Soviet factories and collective farms who came from other parts of the Soviet Union (Riekstiņš 2004, Bunkše 2007).[6] For the deportees sent to Siberia, contrary to the workers relocating to Soviet Latvia, displacement was not followed by the bright socialist future, but rather by the arduous construction of a new life in the often physically and socially challenging, if not outright hostile, environment of the new settlement (e. g. Kalniṇa 2001, Manfelde 2010). 
Deportations to Siberia in the previous century and the Great Departure of this century are widely thought of as consequential for the life of the cultural nation as a result of their displacing of Latvians from their national territory. Most importantly, however, the deportations and the Great Departure also reconfigured tangible social and material relations constitutive of a particular kind of emplaced life. Consequently, an alternative way to think of the Great Departure is not in terms of migration, but in terms of the relationships and practices of both the people on the move and those that have remained behind. Instead of reading the rhetorical comparison between Siberia and Ireland as a tale of migration conceived in relation to the nation, it is possible to read it as a tale of severed and reworked relations. An important element of analysis that aims to loosen the grip of the national(ist) common sense is tracing when and how these relations and practices become articulated as matters of migration and as matters of concern to the nation. For example, even as the film focused on the severance of relationships with relatives, homes, and surroundings that resulted from the move to Ireland or England, the comparison with Siberia invited reflection on the collective aspects of the departure. Such comparison was made possible by an assumed historical continuity between the collective subject affected by the Soviet deportations and the collective subject affected by the Great Departure. In both cases this collective subject was the Latvian cultural nation. Such comparison posits the national subject as a privileged historical subject which both suffers from the deportations and is affected by the Great Departure. Given the hegemony of the national(ist) common sense in Latvian public and political life, there are hardly any other options available for how to think about migration on the collective register. Other collective identifications - such as ones based on socio-economic inequalitieshave either been discredited due to widespread aversion to leftist politics after collapse of the Soviet Union or do not have a sufficient popular base. Thus, the filmmakers' engagement with the Great Departure oscillates between the experiences of concrete people and the fate of the nation. While the filmmakers suggest that, once again, the nation is being scattered across geographical space, they also provide a glimpse of the relations and practices that make up concrete journeys. The hard work of constructing alternatives to national(ist) common sense requires building upon the tangible relations of displacement and emplacement that these journeys make visible.

The deportations carried out by the Soviet administration ruptured families, separated people from their homes and their lifeworlds. All in all, deportations 
affected not only those who were deported, but also those who stayed behind and were faced with missing family members, missing neighbours, and empty homesin other words, found themselves amidst unravelled social fabric. The departures of today also sever family relations, leave behind empty homes, and radically remake life in concrete localities. One woman in a town near the Russian border told me how painful and abnormal it is that she is not able to have an unmediated relationship with her son who lives in Ireland. She said: 'If he only lived in Riga [the capital city of Latvia], I could at least bring him potatoes or something, but now, nothing. Now only moral support'. She was not satisfied with providing only moral support through email or on the telephone. She longed for a tangible relationship.

At the same time, some of those who return home for a visit note that they cannot reconstruct the relationships they had before leaving. In a recent interview with me, a young man from a small town on the West coast of Latvia who has been working in Ireland initially narrated his visit home as a return to the national homeland where even the air feels special. 'You can feel it in the air when you disembark in the Riga Airport', he said. And yet, even after recounting the difficult working life on Irish fishing boats, he remarked that he is planning to leave again, because the social relations that made up his town as a place of living have disintegrated. There are fewer people around, and he cannot find a common language with his friends. He feels propelled to leave. He experiences this as a burden. He has even advised a friend not to leave, if at all possible, otherwise he will not find a path of return.

This is to say that practices of mobility-even those shaped by national(ist) common sense-displace people from concrete social and material relations that make up life and place. Doreen Massey argues that 'to travel between places is to move between collections of trajectories and to reinsert yourself in the ones to which you relate' (2005: 131). That is, it means establishing or severing the relationships with 'collections of trajectories' that make up a coherent sense of place. Massey describes how going or returning to a place entails joining or rejoining concrete debates, picking up on practices that may have been left behind, finding out what has been happening in one's absence. In other words, it is a weaving together of stories and embodied habitual practices which make something 'here and now' (2005: 131). Thus, 'what is special about place is not some romance of a pre-given collective identity', but rather 
throwntogetherness, the unavoidable challenge of negotiation of a hereand-now (itself drawing on a history and a geography of thens and theres); and a negotiation which must take place within and between both human and non-human. (Massey 2005: 140)

Moreover, Massey's analytic of relationality as applied to place is not simply an argument for tracing flows and relations, but rather, as I read it, an invitation to trace the ways in which relations are articulated between trajectories that make up a place and trajectories that make up a subject, thus constituting both the place and the subject in the process. This 'double articulation' results in a coherent narrative of place and of self in relation to it (Massey 1994). The young man above was not able to reinsert himself in the set of trajectories that made up his town as a particular place in relation to him as a particular subject, because the relations and trajectories that constituted both had changed. In other words, the double articulation of subject and place had been substantively altered. So much so that he was inclined to leave.

I have argued thus far that emplacement amounts to inserting oneself or being inserted into trajectories that make up place, whereas displacement means removing oneself or being removed from them. In that sense, one can be displaced even if physically present, as in the case of the young man above. Moreover, particular configurations of emplacement and displacement can be co-opted by national(ist) common sense, but they also exceed it. In order to trace this excess, it is imperative to put a hold on a facile diagnosis of nationalism. I now turn to tracing one historical instance of displacement and emplacement through which l'd like to further illustrate the point.

\section{Peasants, Land, and the Nation}

In the second half of the nineteenth century, the freeing of Latvian peasants from indentured servitude to Baltic German land owners went hand-in-hand with an expansion of capitalism in the Russian provinces. As part of what Karl Marx called 'primitive accumulation' and what David Harvey has expanded upon as 'accumulation by dispossession' (Harvey 2010), Baltic German landlords freed the serfs not only from indentured service, but also from land (Spekke 2008, Strods 1987, Plakans 2006, Škilters 1928, Dunsdorfs 1937). Thus, the peasants, whose existence until then had been tied to land, were freed, dispossessed, and displaced all at once. Hearing of cheap land in Russia, many peasants set on the road. 
Historian Vita Zelče (1999) describes one episode in this historical instance of departure whereby Krišjānis Valdemārs, a prominent Latvian intellectual studying and working in St. Petersburg, had purchased some land $70 \mathrm{~km}$ from St. Petersburg. He was planning to sell off some pieces to other Latvians and settle on the rest himself. After great initial interest from the peasants, Valdemārs purchased more land and thus set into motion what became a chaotic emigration campaign. Trying to curtail the flow of too many ill-informed peasants unprepared for life on the new land, Valdemārs wrote to a priest in one of the parishes in Kurzeme, asking him to inform his parish and the neighbouring parishes that there was not enough land for everyone and that the first year would be very difficult until the harvest came in (Zelče 1997: 111). Valdemārs also wrote that such a mass exodus was of concern from the perspective of the Latvian nation-in-formation. Prior to the second half of the nineteenth century, ethnicity and class overlapped insofar as Baltic German landed elites dominated Latvian peasants. After being freed from servitude to land and German lords, the peasants did not act particularly Latvian in their search for their own piece of land. However, this was also the time of 'national awakening', when Latvian intellectuals, educated in Tērbata and St. Petersburg, actively worked on the consolidation of the cultural nation of Latvians within the political boundaries of the Russian Empire. In his letter to the priest, Valdemārs already thought in national categories. He expressed concern that the mass departure of peasants might have negative consequences for the nation-information. The peasants were, after all, its popular base.

The national elites emerging in the late nineteenth and early twentieth centuries (much before the establishment of the Latvian state in 1918) subsequently rendered this historical departure as animated by a 'desire for departure' (izcel,ošanas kāre) stemming from an unenlightened worldview and lack of concern for the nation (see Škilters 1928: 5). The forming of the national(ist) common sense was underway. As the national frame was filled with content over the next century, the relations that the peasants established with land and through which they emplaced themselves in their new settlements came to be seen as features of a particularly Latvian modality of life which differentiated them from other local inhabitants (Sovina 2012).[7] By the end of the twentieth century, when the Soviet Union was crumbling, the descendants of the Latvian peasants residing in Russia were co-opted by the national(ist) common sense and their portrayal as a diaspora that has always struggled to maintain Latvianness far away from their homeland (Sovina 2012). The social and material relations of emplacement through 
which Latvian peasants and their descendants crafted their lives-even if not in their rightful national territory-became articulated as ethical practices constitutive of the Latvian way of life. Subsequently, people who lived their relationship with place differently were thought of as inhabiting a different ethical lifeworld.

In the context of the population transfers and population movement that transpired during the Soviet period, many people from other parts of the Soviet Union came to reside in Latvia. Thus the population movement not only entailed the displacement of Latvia's residents, but also the emplacement of a large number of newcomers. The particular contours of this emplacement were shaped by the Soviet state's attempts to dilute Latvian nationalism, which meant that the newcomers were not encouraged to learn the Latvian language or to respect the local ways (Dzenovska n.d., Pabriks 2003). As a result, the figure of the migrant emerged as an especially stark aberration to Latvian understandings of the good life. This figure, however, was not just someone who had crossed a national boundary and did not belong in the national space. It was someone who inhabited place differently.

\section{The Figure of the Migrant}

Returning to Latvia for the first time in the late 1980s after decades of living in Canada as a post-World War II refugee, geographer Edmunds Bunkše (2007) describes how he rode the train from Leningrad to Riga longing to see a rural landscape consisting of single farmsteads he remembered from his childhood during World War II. After having crossed the unmarked border of Soviet Latvia, Bunkše set out to visit the single farmstead that had been his childhood refuge in times of war and where the extended family of his grandmother had resided:

Driving on the Riga-Pleskava highway-it was as empty as I remembered it; only once in a while punctuated by some truck with large, white plates with Cyrillic letters in the back-I was very anxious. [...] When we got closer to the area, the landscape became hilly and the road wove up and down. The view included pine and birch trees, as well as some single farmsteads. When we came to the right place, I slowly recognized the contours of the landscape. That's how you feel when you meet a person whom you have known as a healthy and whole being, but who has been seriously crippled by some accident or hard life. 
The road leading up to the house over a hill was no longer straight; it now hugged a large pond, which had developed from a dirty and over-grown drainage ditch stretching along the highway. When we reached the muddy and uneven road, I saw that the animal barn and the thrashing barn no longer stood in their place. The horse barn was still standing, its stone walls like before, but the roof had many holes in it. The residential building was in its place, but its long roofline had bent inward on both ends. The house was surrounded by chaotically demarcated vegetable gardens (though it was still winter). [...]

A bony, yellow-brown dog with low hanging ears barked at us viciously. An older man and a woman, both in worn out clothing, came out the door to meet us. They were both Russian. My companions, who spoke Russian, decided that we should ask to be let in. I objected, but they asked nevertheless. And we were invited into the room, which once was the main living room (the house was now divided into four family apartments). The walls and the ceiling were covered with soot and smelled like soot too. There was a bucket in the middle of the room to collect the rainwater, which was seeping through the roof. (Later I was told that migrants have a characteristically indifferent attitude towards up-keeping homes.) It was painful to see it, but the biggest shock came when my companions told the Russian couple that I belong to the former owner's family. The woman began to weep and, gesticulating with her arms, circled the room. She thought I had come to reclaim the house and to put her out; weeping endlessly, she tried to show me how they had improved the house. Her screams and the bucket of water was more than I could take. I ran outside, behind the home, and bent over to throw up. But I only gagged (2007: 53-54) [9].

Bunkše's narrative invokes the figure of the migrant. Historians attribute the emergence of this figure to the Soviet state's policies, that is, to a concerted effort to relocate large numbers of residents from other Soviet republics to Latvia in order to dilute the nationalist sentiment of the population and to create material conditions for the cultivation of a Soviet people (Riekstiņš 2004). However, Bunkše's narrative shows that the figure of the migrant is not only a state-based 
category marking people who came or were recruited as part of the Soviet state's population politics. In the social imaginary, the migrant is also someone who has a qualitatively different mode of inhabiting place from those who are understood as having and taking the proper care for one's surroundings. At the same time, given the Soviet and post-Soviet political legacies, Bunkše's narrative also maps ethical difference onto ethnic difference by emphasizing that the current inhabitants of his grandmother's house are both Russians and migrants. And yet, his concern takes on concrete contours not through a focus on the fact that the new residents are Russians, but rather through a detailed description of how they had inhabited and cared for the space.

On the one hand, the emphasis on the relationship with place as central to national identity and thus to an ethical way of life resonates with Malkki's (1992) argument that national(ist) discourses moralize rootedness or, more precisely, pathologise uprootedness. On the other hand, as Bunkše's narrative indicates, it is important to ask what kind of conduct is taken to be indicative of a proper relationship to place rather than simply stating that a relationship to place is important. In other words, the 'migrant' is othered not because she or he is of different blood, but rather because she or he does not care for place in a proper way. The details of emplacement and displacement get overlooked when nationalism is used as shorthand for explaining the figure of the migrant.

A case from a rural municipality in the Western part of Latvia will help to illustrate this further. In a conversation about the Great Departure, the head of the municipality told me that he thought that the local cultural identity was under threat due to emigration. 'Over the course of the last 70 years, three out of four people have disappeared', he noted, 'Only patriotism and economy can save us'. In his view, this amounted to the need for proactive cultivation of the local cultural identity not only as a communal or ideological project, but also as an economic one. In recent years, the municipality had obtained UNESCO funding for the preservation of their unique cultural space. The development vision of 'patriotism and economy' had proved to be viable so far. Yet not all the residents of the municipality supported it:

We see that there is a big difference between people who have local roots, those who have the local feeling, and those who have come here as migrants from elsewhere. We have some incomers here who are very negative towards what we do here. We have a similar situation to what 
Latvians have in Riga with the Russians who do not care about all this and would rather be part of Russia. Here we have the same thing. They [incomers] are from another place, and they think that the local culture is not necessary, that there are not many of us, and that therefore there is no need for further distinctions [author: between the specifically local identification and identification with Latvians more general/y].

However, through my extended presence in the township I was able to observe that many of those who were deeply involved in furthering local identity in this municipality identified themselves as ienācēji (incomers). This term usually came up when we had reached a point in the conversation where the person felt the extent of their knowledge about local history or politics had reached some limit or when they began to feel that they sounded too patriotic. It was rarely in response to a direct question about personal history and was almost always brought up by the person himself or herself. When I brought this up with the head of the municipality, our further conversation complicated the seemingly simplistic juxtaposition between locals and incomers:

Author. But you have incomers-people from other places, other municipalities-that are strong supporters and cultivators of local identity.

Head of Municipality. Thank God, we have them. Some of them are very good people. For example, Liene is not a local. Her husband is. We have some very good examples. Some of the members of the local women's folklore group are not locals. It's called integration. We don't have anything against incomers, but if the incomer comes and starts dictating his or her rules...

Author. So does that mean that people become incomers because of the way they behave? Does that mean that those who have integrated are not incomers?

Head of Municipality. No, I would not consider them such. There are some purists who would, but I disagree.

Our conversation seemed to be strongly coloured by national(ist) common sense about migration and integration insofar as the head of the municipality drew a comparison between the local-incomer relationship in his municipality with the 
nationally recognizable juxtaposition between locals (Latvians) and migrants (Russians). Moreover, he used the notion of integration-the politically instituted model of regulating the relationship between Latvians and Russians in public space-to describe the desired state of affairs with regard to incomers and locals. The metaphoric equation of locals with Latvians and incomers with Soviet-Russian migrants missed the daily practices of living, which made one local-the crafting of relations of locality through participation in community projects. And it is precisely the tracing of these practices and relations-the same ones that the head of the municipality represented through the juxtaposition between the locals and the incomers or between Latvians and Soviet-Russian migrants-that might also entail the possibility to loosen the national(ist) interpretations of mobility and to proceed with analysis of the tangible relations of emplacement and displacement.

My approach here resonates with Matei Candea's (2010) analysis of place in Corsica. In his book Corsican Fragments: Difference, Knowledge and Fieldwork, Candea deploys a relational analytic to show how the allegedly essential relationship between people and land in Corsica is 'put together, ... how it emerges from connections which are themselves contingent and shifting' (2010: 81). Candea does this by describing how the residents and visitors live a fire that breaks out in forests adjacent to a Corsican village, that is, how locality is constituted through watching a fire. In doing so, Candea puts forth a critique of the metaphorisation of the people-land relationship, which quickly leads down the treaded road of positing references to a relationship between people and land as nationalist. To push the idea further, it can be said that the historical tradition of treating references to the relationship between land and people (or place and people) as nationalist leads to a reduction of thick networks of relations that are quickly abstracted or fold into national(ist) commonsense. Yet, Candea is also careful not to assert radical difference as a way to counter such diagnostics. Instead, Candea suggests that what is needed is a meticulous tracing of shifting relations through which place and locality are constituted. However, Candea asks: if watching a fire is one of the many ways of becoming local, then whence does the boundary making between locals as related to land and foreigners as not related to the land arise? How are shifting and contingent relations fixed as juxtapositions between locals and foreigners? From Candea's text, one can conclude that it happens when the locals, the foreigners, and their anthropologists turn to available framing devices to locate themselves in relation to their surroundings and 'to manipulate scale and context' (2010: 83). It is what the Corsicans do when they depict tourists as 
disconnected from the locality. It is what the head of the municipality in Latvia did when he drew a comparison between local incomers and national migrants.

The implication of this for the scholarly analysis of mobility is that the search for alternative analytics to nationali(ist) common sense is not to be found in new objects of study, but rather in the bracketing of hegemonic interpretive framesincluding the one that allows an identification of particular practices as being tainted by nationalism, methodological or otherwise. Consequently, the figure of the migrant emerges as a historically constituted character who acts in a way that demonstrates the relationships Latvians inhabit and the consequential differences they fix within the network of these relationships in particular historical moments. Rather than (or in addition to) a sociological category, it is a kind of a heuristic device devised through conceptual work done by ordinary human beings to make sense of the world, to organize the world ethically in relation to emplacement and displacement. [8]

\section{Ethics in the Context of the Great Departure}

The extent of the Great Departure is challenging the historically formed ethical configuration within which the migrant-as someone merely searching for a better life-is an aberration. The stories of concrete individuals both departing (and staying) exhibit a great degree of variety and cannot be easily subsumed under stable ethical configurations. Some people leave because they cannot find work, others because they cannot make the ends meet with the salary they receive. Many leave because they cannot make mortgage payments or repay consumer credits as a result of having indulged in the credit orgy literally pushed upon Latvia's residents by banks and businesses before the crisis hit in 2008 (Beliaev \& Dzenovska 2009).[9] Some people leave because their friends and relatives are already 'there' and convey information that it is possible to live rather than merely exist on the money that one earns even for manual labour. In one small township in Latgale, people were telling me how one young man from the township went to Ireland, found work, and then returned to take all his friends with him. Finally, some people articulate their decision to go to Ireland or England as arising from dissatisfaction with particular features of Latvian society, such as excessive bureaucracy, oppressive and unfriendly public sociality, or corrupted politics (SAK 2006). Even among those who stay, the departure is ever present not only because their relatives and friends have left, but also because they themselves continuously think about leaving and almost daily justify to themselves why they have not left. 
Most of my informants regularly comment upon why they are still in their village, some explaining that they have to take care of elderly parents while others think themselves too old or too ill to set on the road. There are those who also say that they could never leave their home or leave Latvia. All in all, those who stay are not capable or do not wish to sever their relations of emplacement, which are always complex articulations of multiple trajectories. In conditions of massive departure and reconfiguration of the social fabric, their staying seems to require continuous reflection and justification. They too inhabit what Glick Schiller and her colleagues have called a 'transnational social field' (Basch, Glick Schiller and Szanton Blanc 1994, Levitt \& Glick-Schiller 2004).

In the rural areas that I work in, the departure is mostly perceived as unfortunate, but inevitable. However, in Latvian public and political life, the departure is often negatively evaluated as an unjustified striving for a better life and dangerous for the collective life of the nation. A conversation that ensued during one of my fieldwork trips is a good example of such an attitude. Upon finding out that I too was leaving after the end of the project that brought me to Latvia, a man who was visiting one of my informants and whom I had not met before urged me to explain why I was leaving. Sensing that a lesson in ethics was underway, I meekly suggested that it is literally impossible to live on the salary that awaits me at the end of the project. Having received the answer he expected, the man instantly and rhetorically asked me: 'But you are dressed, right? You are warm?' He implied that my desires and expectations probably exceed my basic necessities, thus my departure is ethically questionable. I proceeded to add that it was not only about financial survival, that I also felt constrained by bureaucratic obstacles and structural shortcomings and that I needed to reinvigorate my intellectual capacities and motivations. He had an answer to that as well, suggesting that nothing prevents me from reading here, in Latvia, so why do I strive to leave? The man wanted to make the point that there simply was no good reason for my departure other than an ethically unjustifiable desire for more than I needed for basic survival.

While the conversation was unfolding, I was observing the man who seemed to enjoy more than just the basic necessities of life and was wondering to myself about the kind of subject position one must inhabit to be able to suggest that other people should be content with the kind of life they have. I later found out in an unrelated conversation with my informants that he owned a wood-cutting facility and was apparently known for trying to pay his employees as little as possible. Thus, while it may have seemed that the man was a patriot who wanted to keep 
Latvians in Latvia, it turned out that he also wanted cheap labour and thought that his employees, as well as I, were unjustified in our striving to alter our conditions of existence. Evidently, the dilemma of whether it is ethically acceptable to move in search for a better life is always already entangled with the materiality of life and discussions of mobility and stasis must be situated within an analysis of unequal power (Glick Schiller and Salazar this volume).

The argument about whether it is justified to leave in conditions when life may be difficult, but not physically unlivable, saturates public discourse and everyday conversations. While many of those who stay insist that those leaving want to have an easy life for themselves rather than work hard at home to make the collective life better, this argument is increasingly undermined by more and more people setting on the road. In conditions when so many people traverse a transnational social field, attention is increasingly paid to the kind of ties they maintain or establish with home. Many of those who have left frequently return home for a variety of services. As one woman told me, she comes back to Latvia for a 'technical check-up,' that is, she visits a gynaecologist, a dentist, and a hairdresser. Others come back to attend festivities in their home villages, to monitor the renovation of their property, as the woman I met on the Ryan Air flight, or simply for a holiday. A variety of government and non-government institutions and organizations try to understand these ties and cultivate those that are thought beneficial for the state and the nation. For example, the Ministry of Foreign Affairs of Latvia is actively working on the development of diaspora politics, which at the current moment requires an effort to convince the public that it is advantageous for everyone that the government spends money on cultivating ties with the Latvian diaspora. Other states, such as Lithuania and Ireland, are invoked as exemplary in having understood the value of the diaspora for national well-being.

Overall, the extensive reconfiguration of the social fabric brought about by the Great Departure is demanding a rethinking of ethics, as well as a rethinking of the nature of the hegemonic collective subject, that is, of the nation. It seems that the long-assumed stable foundation of the nation as the articulation of national subjects with national territory is being unsettled. As demonstrated by scholars working on diasporic nationalism (e.g. Bernal 2004, Glick-Schiller and Fouron 1999), this does not necessarily mean doing away with national(ist) common sense. In fact, it might even mean a strengthening of the national sentiment. However, even if so, the severance of the articulation between the nation and the territory through tangible relations of displacement and emplacement cannot but remake the 
collective subject. Whether and how this will happen remains an ethnographic question which requires a careful tracing of the ties that link people to each other and to particular places, that is, it requires a careful study of the relations of displacement and emplacement and of the double articulation between subjective and spatial trajectories. The difference between the nation 'as we know it' and the formation of a new collective subject lies in the sociality formed by particular relations of displacement and emplacement, as well as in the ability to see novel possibilities in seemingly familiar configurations of politics, ethics, and analytics.

\section{Acknowledgments}

I would like to thank the editors of the special issue for inviting me to participate in this collective project. I would also like to thank Iván Arenas for reading and commenting various versions of this article. This research was made possible by the the University of Latvia / European Social Fund grant 'Changing Development Strategies and Cultural Spaces of Latvia's Rural Inhabitants,' (2009/0222/1DP/1.1.1.2.0/09/APIA/VIAA/087).

\section{Notes}

[1] A local TV station (TV3) produced a documentary series entitled 'The Great Departure' where they interviewed people as they were preparing to leave and subsequently followed them as they were trying to make a new life in England, Ireland, and later in Germany.

[2] See www.csb.gov.lv

[3] For example, such prognoses were put forth by the Minister of Economy during a conference 'Migration and Identity: Strengthening the Role of Diaspora', organized by the Ministry of Foreign Affairs and the Jean Monett Centre for Excellence of the University of Latvia in March, 2012.

[4] It is important to note that the conception of the nation operative in Latvia is one of a cultural nation, which is linked to, but also separable from the political entitythe Latvian state-that is supposed to ensure its existence. See Verdery 1994 on the specificity of the conception of the nation in Eastern Europe and its implications for theorizing transnationalism. It should also be noted here that much of the scholarship on migration that works Foucault's analytic is mostly concerned with the ways in which states regulate migration and treat migrant bodies as expendable rather than as integral to the living body of the nation or society and thus subject to the disciplinary and exclusionary politics of the state (De Genova and Peutz 20101, 
Mandel 2008, Hyndman 2000, Mountz 2010, McDowell 2005). Scholarship that focuses on the cultivation of the social body through work upon the body itself (rather than through exclusion of those who do not belong to it), usually is concerned with pro-natal politics (Paxson 2004, Greenhalgh and Winckler 2005), though concern with migration appears in Karen-Sue Taussig's (2009) study of genomics in the Netherlands.

[5] In her work on the metaphysics of sedentarism, Liisa Malkki has argued that the naturalized articulation of place and identity in nationalist discourses has produced the pathological figure of the refugee which is thought to lose its moral bearings as a result of losing its bodily relationship to the homeland (1992: 32).

[6] It should be noted that many people also set out as refugees before the Soviet regime was re-established in 1945 . They did so largely due to the experience of repressions of the first Soviet government in 1940. The refugee life is described in works such as Žìgure 2009, McDowell 2005, and Zaḳe 2010. Similar to deportees, refugees too experienced a violet rupture of their network of relations.

[7] See Anna Sovina's MA thesis "Bashkirians" and "Bashkirian Latvians": Tension between the Social and the National Registers", University of Latvia. Sovina describes how particular practices of land cultivation and inhabiting of place, such as growing flowers, came to be seen as particularly Latvian features that distinguished descendants of the Latvian peasants from Russians and Baskhirs.

[8] Analytically, I think of this figure as a combination of Max Weber's ideal-types and Alasdair MacIntyre's characters. On the one hand, it is akin to the figures Weber uses in his historical work to illustrate ideal-typical conduct, such as how Benjamin Franklin is used to illustrate specific ideas about work as a religious calling in Weber's The Protestant Ethic and the Spirit of Capitalism (2003). On other hand, it resonates with Maclntyre's characters-for example, the manager-which define the possibilities of plot and action. They are not simply social roles; rather, 'they are very special type of social role which places a certain kind of moral constraint on the personality of those who inhabit them' (1984: 27).

[9] Author's translation.

[10] I have had several bank employees confidentially tell me about the internal policies during the time period before the crisis whereby credit departments were encouraged to push credits in all possible ways and bank employees received bonuses for selling more and more credit.

\section{References:}


Balibar, E. (2010) 'At the Borders of Citizenship: A Democracy in Translation?', European Journal of Social Theory, 13(3): 315-322. (2003) We the People of Europe: Reflections on Transnational Citizenship. Princeton: Princeton University Press.

Bash, L., Glick Schiller, N., and Szanton Blanc, C. (1994) Nations Unbound: Transnational Projects, Postcolonial Predicaments, and Deterritorialized Nation-States. New York: Gordon and Breach [Routledge].

Beck, U. (2004) The Cosmopolitan Vision. Cambridge: Polity Press.

Beliaev, A. and Dzenovska, D. (2009) 'Some Reflections on the "Global" Crisis in Latvia', Newsletter of the Institute of the Slavic, East European, and East Asian Studies, 26(2): 3-6.

Bernal, V. (2004) 'Eritrea Goes Global: Reflections on Nationalism in a Transnational Era', Cultural Anthropology, 19(1): 3-25.

Bunkše, E. (2007) Intīmā Bezgalība. Rīga: Norden AB.

Candea, M. (2010) Corsican Fragments: Difference, Knowledge, and Fieldwork. Bloomington: Indiana University Press.

De Genova, N. and Peutz, N (eds). (2010) The Deportation Regime: Sovereignty, Space, and the Freedom of Movement. Durham: Duke University Press.

Dunsdorfs, E. (1937) Klaušu beigu cēliens Kurzemē. Rīga: Latvijas Vēstures institūts. Dzenovska, D. (n.d.) 'How to Be a Minority: The Politics of Conduct and Difference in the New Europe', in Gille, Z. (ed) What Was Post-socialism and What Comes Next? Whiteness, Transparency, and the Politics of Care in a Global Context.

Escobar, A. (2001) 'Culture sits in places: reflections on globalism and subaltern strategies of localization', Political Geography, 20 (2001): 139-174.

Foucault, M. (2003) Society Must Be Defended: Lectures at the College de France, 1975-1976, Macey, D. (transl). New York: Picador.

Gibson-Graham, J.K. (2006) A Post-Capitalist Politics. Minneapolis: University of Minnesota Press.

Glick Schiller, N. and Fouron, G.E. (1999) 'Terrains of Blood and Nation: Haitian Transnational Social Fields', Ethnic and Racial Studies, 22(2): 340-366.

Greenhalgh, S. and Winkler, E. (2005) Governing China's Population: From Leninist to Neoliberal Biopolitics. Stanford: Stanford University Press.

Gupta, A. and Ferguson, J. (1992) 'Space, Identity and the Politics of Difference', Cultural Anthropology, 7(1): 6-23.

Hacking, I. (2007) 'Kinds of People: Moving Targets', Proceedings of the British Academy, 151: 285-218. 
Harvey, D. (2010) The Enigma of Capital and the Crises of Capitalism. Oxford: University of Oxford Press.

Hazans, M. (2011) 'Latvijas emigrācijas mainīgā seja 2000-2010', in SPPI, ed, Latvija. Pārskats par tautas attīstību. 2010./2011. Nacionālā identitāte, mobilitāte, rīcībspēja, Rīga: Latvijas Universitātes Sociālo un politisko pētījumu institūts, 79-91.

(2005) Ekonomiskās migrācijas cēloṇu izpēte un monitoringa sistēmas izveide ekonomiskās migrācijas ietekmes noteikšanai uz $L R$ tautsaimniecību. Report to the Ministry of Economy of the Republic of Latvia.

Hyndman, J. (2000) Managing Displacement: Refugees and the Politics of Humanitarianism. Minneapolis: University of Minnesota Press.

Kalniṇa, S. (2010) Ar balles kurpēm Sibìrijas sniegos. Rīga: Atēna.

Levitt, P. (2001) The Transnational Villagers. Berkeley: University of California Press.

Levitt, P. and Glick Schiller, N. (2004) 'Conceptualizing Simultaneity: A Transnational Social Field Perspective on Society', International Migration Review, 38(3): 1002-1039.

Lulle, A. (2010) 'New Others: Identity Construction and Transnational Belonging Among Latvian Migrants to Guernsay', EastBordNet Working paper.

Maclntyre, A. (1984) After Virtue: A Study in Moral Theory. Notre Dame: University of Notre Dame Press.

Malkki, L. (1995) Purity and Exile: Violence, Memory, and National Cosmology among Hutu Refugees in Tanzania. Chicago: University of Chicago Press. (1992) 'National Geographic: The Rooting of Peoples and the Territorialization of National Identity Among Scholars and Refugees', Cultural Anthropology, 7(1): 24-44.

Mandel, R. (2008) Cosmopolitian Anxieties: Turkish Challenges to Citizenship and Belonging in Germany. Durham: Duke University Press.

Manfelde, A. (2010) Zemnīcas bērni. Rīga: Autora izdevums.

Massey, D. (2005) For Space. London: Sage.

(1994) 'Double Articulation: A Place in the World', in Bammer, A. (ed) Displacements: Cultural Identities in Question. Bloomington: Indiana University Press, 110-119.

McDowell, L. (2005) Hard Labor: The Forgotten Voices of Latvian Migrant Volunteer Workers. London: UCL Press.

Mountz, A. (2010) Seeking Asylum: Human Smuggling and Bureaucracy at the Border. Minneapolis: University of Minnesota Press. 
Pabriks, A. (2003) In Defiance of Fate: Ethnic Structure, Inequality, and Governance of the Public Sector in Latvia. UNRISD

Paxson, H. (2004) Making Modern Mothers: Ethics and Family Planning in Urban Greece. Berkeley: University of California Press.

Plakans, A. (2006) 'Migration, Households and Agrarian Reform in the Baltic Provinces of Russia: 19th and 20th centuries', History of the Family, 11 (2006): 151-159.

Riekstiņš, J. (2004) Migranti Latvijā. 1944-1989. Dokumenti. Rīga: Latvijas Valsts Arhīvs.

Šḳilters, K. (1928) Latkoloniju vēsture. Maskava: Prometejs.

Sovina, A. (2012) 'Bashkirians' and 'Bashkirian Latvians': Tension between the Social Register and the National Register, MA thesis, University of Latvia.

Spekke, A. (2008) [1948] Latvijas Vēsture, Rīga: Jumava.

Stratēǵiskā analīzes komisija. (2006) Latvija un brīva darbaspēka kustība: İrijas piemērs. Rīga: Stratēǵiskās analīzes komisija.

Strods, H. (1987) Kurzemes kroṇa zemes un zemnieki, 1795-1861, Rīga: Zinātne.

Tausig, K. (2009) Ordinary Genomics: Science, Citizenship, and Genetic Identities. Durham: Duke University Press.

Torpey, J. (1998) 'Coming and Going: On the State Monopolization of the Legitimate “Means of Movement"', Sociological Theory, 16(3): 239-259.

Verdery, K. (1994) 'Beyond the Nation in Eastern Europe', Social Text, 38 (Spring, 1994): 1-19.

Weber, M. (2003) [1904-05] The Protestant Ethic and the Spirit of Capitalism. Minneapolis: Dover Publications.

Wimmer, A. and Glick Schiller, N. (2002) 'Methodological Nationalism and Beyond: Nation-State Building, Migration, and the Social Sciences', Global Neworks, 2(4): 301-334.

Zak̦e, I. (2010) American Latvians: Politics of a Refugee Community. New Brunswick: Transaction Publishers.

Zelče, V. (ed) (1997) Krišjānis Valdemārs: Lietišḳā un privātā sarakste. Pirmais sējums: Krišjāṇa Valdemāra vēstules. Rīga: LVVA.

Zelče, V. (1999) 'Pirmā latviešu emigrācijas kampaṇa', Latvijas Arhīvi, 1999(3): 7688.

Žīgure, A. (2009) Viṇi. Celāa. Rīga: Jumava. 